\title{
Natural monopoly and differential pricing
}

\author{
Marcel Canoy
}

No. 9411

Correspondence:

CEPREMAP

142, Rue du Chevaleret

75013 Paris

In drafting the paper I benefitted greatly from discussions with former colleagues at the University of Amsterdam, as well as with colleagues at CEPREMAP. I would like to thank two anonymous referees for their constructive comments that helped to improve the paper. An earlier version of the paper appeared as Chapter 4 in my PhD-thesis. 


\section{SUMMARY}

\section{NATURAL MONOPOLY AND DifFERENTIAL PRICING}

Under uniform pricing a monopolist cannot make a positive profit in equilibrium. Uniform pricing is an unnecessary restriction. In the paper I analyze how differential pricing can be exploited by a natural monopolist to deter entry when entry is costless. In a two-stage game with price competition before quantity competition I show that the incumbent firm can deter entry and make a positive profit in equilibrium. The incumbent sets two different prices, the low price to deter entry and the high price to generate profit. Entry is not possible because of scale effects. I show that for some parameter values the incumbent is forced to engage in a stunt (i.e. set a negative low price) to keep entrants out.

\section{RÉSUMÉ \\ MONOPOLE NATUREL ET DisCRIMINATION PAR LES PRIX}

Dans le cas des prix uniformes une firme monopoliste ne peut pas bénéficier d'un profit positif à l'équilibre. L'uniformité des prix n'est toutefois pas une restriction nécessaire. Je montre dans cet article comment une firme monopoliste peut exploiter une discrimination par les prix pour acquérir un profit positif et ainsi empêcher l'entrée sur le marché. Dans un jeu à deux étapes, avec concurrence par les prix avant concurrence par les quantités, je caractérisé l'ensemble des équilibres admissibles. La firme monopoliste fixe deux prix différents, un prix bas pour empêcher l'entrée et un prix haut pour acquérir un profit. En raison de rendements d'effets d'échelle, l'entrée n'est alors pas possible parce que il y a des effets d'échelle. Je montre que, pour certaines valeurs des paramètres, la firme monopoliste sera amenée à fixer une valeur de prix bas négative à l'équilibre.

Mots clef: Monopole naturel, discrimination par les prix, jeu à deux étapes, empêcher l'entrée.

Key words: Natural monopoly, differential pricing, two-stage game, entry deterrence.

JEL classification: D 40, D42, L40 


\section{Introduction}

The issue of entry deterrence in natural monopoly models merited a lot of attention in the eighties. In their book Baumol, Panzar and Willig (1982) put forward their theory of contestable markets as a unifying pure theory on the issue. In the discussion on contestable markets Tirole (1989) argued that it is better to study the equilibria of an appropriate game than the contestable outcomes. He considered a two-stage game with price-setting before quantity-setting. It can be shown that under uniform pricing an equilibrium exists in such a game and the firms make zero profits (Tirole 1989). The timing in the game has been criticized on the ground that prices seem to adjust more rapidly than quantities. In this paper I provide a justification for the use of the two-stage game when prices are set first. The incumbent firm can use differential pricing to deter entry and make a positive profit in equilibrium. The typical economic situation is the following. By setting a low price one firm attracts a first group of customers to gain the advantage over competitors, and subsequently it exploits the increasing returns to scale technology to generate a profit. Such a "loss leading" strategy is not an uncommon marketing strategy. For instance, in the airline industry the first customers can often buy at a lower price than the last customers. I show that differential pricing can lead to a Pareto improvement over uniform pricing. Firms can deter entry and make a profit while consumers are not worse off (and possibly better off) than under uniform pricing.

I distinguish various regimes of differential pricing. I allow for the possibility that pricing below average costs, which I call dumping, is prohibited, since that is the case in some countries, particularly in the United States where the Robinson-Patman Act prohibits price discrimination where the effect "may be substantially to lessen competition or tend to create a monopoly...", (Scherer and Ross 1990). The Robinson-Patman Act is controversial since the effects of price discrimination on competition and welfare are by no means clear. I characterize the equilibria under uniform pricing and under the various regimes of differential pricing. I show that in most of the cases the equilibria are unique under fairly mild assumptions about cost and demand. I show that welfare is the highest when dumping is prohibited. So when dumping is used to deter potential entry, the Robinson-Patman Act is justified.

Perry (1984) scrutinizes the contestability hypothesis in a multiple-price environment. His most important result is that, despite free entry, a natural monopolist can make a positive profit and prevent entry. I re-establish this result in a more general framework. I allow for arbitrary sharing rules and I show that Perry's result only holds if firms are not allowed to price below average costs. ${ }^{1}$ Moreover, I show that if dumping is allowed it is possible that incumbents must set a negative price to deter entry, i.e., the incumbent must engage in a stunt to keep entrants out.

Differential pricing (see Braeutigam 1989) is closest to third-degree price discrimination, the

\footnotetext{
${ }^{1}$ Perry makes the strong assumption that all consumers buy from the incumbent at equal prices. Also he considers supply functions as the strategic variable and he allows for resale. Finally, he does not prove uniqueness nor does he consider welfare comparisons.
} 
difference being that firms set prices and quantities without the requirement of using exogenous information to segment the market into identifiable subsets of consumers. ${ }^{2}$

One may associate incumbent-entry problems with a sequential framework where the incumbent commits to a price-quantity after which potential entrants decide upon entry. However, equilibria in the simultaneous two-stage game are equivalent to the equilibria of the sequential game where the incumbent sells quantity at a low price first (after which potential entrants decide to enter) and the residual quantity at a higher price next (see Canoy 1993). The simultaneous framework is used here because it corresponds more closely to the usual Bertrand game. ${ }^{3}$

\section{The set-up}

The game under consideration looks as follows:

\section{GAME PQ}

STAGE $1 \mathrm{n}$ firms simultaneously set prices $\mathrm{P}=\left(\mathrm{p}_{1}, \ldots, \mathrm{p}_{\mathrm{n}}\right)$.

STAGE $2 \mathrm{n}$ firms simultaneously set quantities $\mathrm{Q}=\left(\mathrm{q}_{1}, \ldots, \mathrm{q}_{\mathrm{n}}\right)$.

I only report the actions of the minimum number of inactive firms required. For example, if two inactive firms are sufficient to establish a threat to the incumbent(s), more inactive firms are superfluous and will henceforth be ignored. The appropriate equilibrium notion is the subgame perfect equilibrium (henceforth: equilibrium). The justification for the use of a simultaneous game is that equilibria of game PQ are equivalent to equilibria of a sequential game, i.e. the incumbent commits first to a price-quantity pair after which potential entrants can react (see Canoy 1993). History has determined that there is one firm that is the incumbent, i.e. one firm has the right to commit first. In the simultaneous game it implies that the incumbent firm 1 will be the active firm in equilibrium (cf. Tirole 1989, p.310, where it is assumed that firm 1 is the incumbent and firm 2 the potential entrant). It is important to notice that this has nothing to do with an a priori advantage in demand of one firm. ${ }^{4}$ Henceforth I label the active firms with low indices and the inactive firms with high indices. So if there are two active firms in equilibrium, the firm with the highest quantity is labeled 1 , the second

\footnotetext{
${ }^{2}$ Mandy (1992) examines whether the Bertrand result still holds under second-degree price discrimination. If dumping is allowed, I obtain a result similar to Mandy's main result that no positive profit is possible in equilibrium.

${ }^{3}$ Benassy (1986) and Friedman (1988) discuss timing in price-quantity games with decreasing returns and without entry threats. Quantity-setting first does not work if the focus is on entry deterrence through differential pricing, since after stage one it is clear who is in and who is not, even before prices are set. Alternatively, a game with simultaneous price and quantity-setting suffers from non-existence problems.

${ }^{4}$ This is unlike the models of Perry (1984) and Sharkey (1982).
} 
with 2 , etc. It turns out that under differential pricing there is only one active firm (firm 1) in equilibrium.

The first aim is to give a characterization of the equilibria if a firm can only set one single price for all customers (which I call uniform pricing). The second aim is to compare the equilibria at uniform pricing with equilibria under differential pricing.

I use efficient rationing to determine residual demand. ${ }^{5} \mathrm{~A}$ sharing rule is needed to determine contingent demand for all prices. Define $J_{i}$ as the set of firms, other than firm $i$, that set $p_{i}$ and set the quantity equal to their share of the demand. The share of demand of firm $\mathrm{i}$ is denoted as $\delta_{\mathrm{i}} \mathrm{D}\left(\mathrm{p}_{\mathrm{i}}\right)$, where $\delta_{\mathrm{i}}$ depends on $\mathrm{J}_{\mathrm{i}}$ and $\delta_{\mathrm{i}}+\sum_{\mathrm{j} \in \mathrm{J}_{\mathrm{i}}} \delta_{\mathrm{j}}=1$. I suppress $\mathrm{J}_{\mathrm{i}}$ in the notation of $\delta_{\mathrm{i}}$.

\section{Definition 1}

Let $Q_{-i}=\left(q_{1}, \ldots, q_{-1}, q_{i+1}, \ldots, q_{n}\right)$ be the vector of quantities when firm $i$ is left out. The contingent demand of firm $\mathrm{i}$ is defined as:

$$
D_{i}\left(P ; Q_{-}\right)=\max \left\{0, \delta_{i}\left[D\left(p_{i}\right)-\sum_{\substack{i \neq j=1 \\ j \neq J_{i}}}^{n} \lambda_{j} q_{j}\right]\right\}
$$

$$
\text { with } \begin{aligned}
\lambda_{\mathrm{j}} & =1 \text { if } \mathrm{p}_{\mathrm{j}} \leq \mathrm{p}_{\mathrm{i}} \\
& =0 \text { if } \mathrm{p}_{\mathrm{j}}>\mathrm{p}_{\mathrm{i}} .
\end{aligned}
$$

A firm may decide to produce less than the contingent demand. This implies that the residual demand is split between firm $i$ and the firms in $J_{i}$ (where $J_{i}$ may be empty). It is implicitly assumed that no firm sets a quantity that is higher than the quantity it actually sells, since it is never optimal to do so. $\mathrm{D}(\mathrm{p})$ is demand at a single price $\mathrm{p}$. At equal prices the market is split somehow. However, it turns out that in equilibrium there are never two active firms charging the same price.

Since I focus on natural monopolies, I restrict attention to a relevant range of total output, on which the cost function $C(q)$ is assumed to be strictly subadditive (see Panzar 1989).

\section{Definition 2}

The cost function is strictly subadditive if for all $\mathrm{q}_{1}, \ldots, \mathrm{q}_{\mathrm{n}}$ :

$$
\mathrm{C}\left(\Sigma \mathrm{q}_{\mathrm{i}}\right)<\Sigma \mathrm{C}\left(\mathrm{q}_{\mathrm{i}}\right)
$$

In other words, the most efficient way to produce total output is to use one firm only. Under efficient rationing the maximum of total output with two active firms is equal to $q_{1}+\left[D\left(p_{2}\right)-q_{1}\right]=D\left(p_{2}\right)$. Let $\left(\mathrm{p}^{*}, \mathrm{q}^{*}\right)$ be the point where the average cost curve (AC curve) reaches its minimum and let both

${ }^{5}$ In Canoy (1993) I showed that the results are not qualitatively effected if proportional rationing (the other popular choice in the literature) is used. 
$\mathrm{p}^{*}<\infty$ and $\mathrm{q}^{*}<\infty$, then total output cannot be higher than $\mathrm{D}\left(\mathrm{p}^{*}\right)$. So to establish a natural monopoly, I assume that demand and cost functions are such that the cost function is strictly subadditive for all total quantities $q=\Sigma q_{i}$ in the relevant range $\mathrm{Z}$ where:

$$
\mathrm{Z} \equiv\left\{\mathrm{q}: \mathrm{q} \leq \mathrm{D}\left(\mathrm{p}^{*}\right)\right\}
$$

\section{Assumption 1}

(i) $\mathrm{C}(\mathrm{q})$ is twice differentiable; (ii) The average cost function $\mathrm{AC}(\mathrm{q})$ is strictly convex; (iii) $\operatorname{Lim}_{\mathrm{q} \rightarrow 0}$ $\mathrm{AC}(\mathrm{q}) \rightarrow \infty$; (iv) $\mathrm{C}(\mathrm{q})$ is strictly subadditive on $\mathrm{Z}$;

Assumption 1(i) to 1(iv) are standard conditions in natural monopoly models. The typical cost function is $C(q)=F+G(q)$, e.g. $C(q)=F+a q^{2}$, which generates a $U$-shaped $A C$ curve with $\operatorname{Lim}_{q \rightarrow 0} A C(q) \rightarrow \infty$.

\section{Assumption 2}

(i) $\forall p$ for which $D(p)>0$ : $D(p)$ is twice differentiable and decreasing; (ii) there exists a $p^{\prime}<\infty$ such that for all $p \geq p^{\prime}: D(p)=0$;

Assumption 2(i) and (ii) are standard conditions. The classic natural monopoly situation is where demand intersects the $\mathrm{AC}$ curve at the downward-sloping part. This is not an interesting case, considering the fact that I want to address the problem of entry deterrence through differential pricing (see also Braeutigam 1989). So I assume that the demand function intersects the AC curve at $\mathrm{q}^{*}$ or to the right of $\mathrm{q}^{*}$, but never higher than $2 \mathrm{q}^{*}$ (due to the subadditivity of the cost function on $\mathrm{Z}$ ). The profit function is given by:

$$
\begin{aligned}
\pi_{\mathrm{i}}(\mathrm{P} ; \mathrm{Q}) & =\mathrm{p}_{\mathrm{i}} \mathrm{q}_{\mathrm{i}}-\mathrm{C}\left(\mathrm{q}_{\mathrm{i}}\right) & & \text { if } 0<\mathrm{q}_{\mathrm{i}} \leq \mathrm{D}_{\mathrm{i}}\left(\mathrm{P} ; \mathrm{Q}_{\mathrm{i}}\right) . \\
& =0 & & \text { otherwise. }
\end{aligned}
$$

The price at which a firm can produce residual demand with zero profits, given that another firm sets a quantity $\mathrm{q}$, is defined as:

$$
\mathrm{p}^{\mathrm{R}}(\mathrm{q}) \equiv \min \{\mathrm{p}: \mathrm{AC}(\mathrm{D}(\mathrm{p})-\mathrm{q})=\mathrm{p}\}
$$

The minimum of prices satisfying $\operatorname{AC}(D(p)-q)=p$ is taken because the equation can have more than one solution. Taking the lowest of all solutions prevents undercutting by other firms. In equilibrium firm 1 has to set $\mathrm{p}^{*}$, since higher prices induce entry in stage 2 . Since no firm can price below average costs, the only feasible quantity firm 1 can produce at $\mathrm{p}^{*}$ is $\mathrm{q}^{*}$. Define residual quantity as:

$$
\mathrm{q}^{\mathrm{R}}(\mathrm{p}, \mathrm{q}) \equiv \mathrm{D}(\mathrm{p})-\mathrm{q}
$$

In a simpler set-up Sharkey (1982) established the following characterization of equilibria in the case of uniform pricing (see also Tirole 1989). 


\section{Proposition 1}

Under Assumption 1-2:

(i) If $\forall p: p<A C\left(D(p)-q^{*}\right)$, the unique equilibrium is $\left(p_{1}, p_{2} ; q_{1}, q_{2}\right)=\left(p^{*}, p^{*} ; q^{*}, 0\right)$.

(ii) If $\exists p$ for which $p \geq A C\left(D(p)-q^{*}\right)$, the unique equilibrium is $\left(\mathrm{p}_{1}, \ldots, \mathrm{p}_{4} ; \mathrm{q}_{1}, \ldots, \mathrm{q}_{4}\right)=\left(\mathrm{p}^{*}, \mathrm{p}^{\mathrm{R}}\left(\mathrm{q}^{*}\right), \mathrm{p}^{*}, \mathrm{p}^{\mathrm{R}}\left(\mathrm{q}^{*}\right) ; \mathrm{q}^{*}, \mathrm{q}^{\mathrm{R}}\left(\mathrm{p}^{\mathrm{R}}, \mathrm{q}^{*}\right), 0,0\right) .{ }^{6}$

In (i) there is no price at which residual demand can be profitably served. Except for firm 1, which is the active firm by construction, no firm will be active. Firm 1 must set its price at $\mathrm{p}^{*}$, since higher prices induce entry in stage 2 (see also figure 1).

In (ii) there are prices at which residual demand can be profitably served. By construction, firm 2 will serve residual demand. Higher prices of either firm induce entry in stage 2 . The basic idea is that if it is technologically feasible to achieve positive profits, potential entrants can be effective in disciplining the incumbents. The fact that four firms are needed in case (ii) can be explained by the fact that, with inactive price-setting firms, inactive firms are committed to a particular price after stage one, so that they can only "discipline" one active firm at a time. The results of Proposition 1 hold for higher numbers of firms, where there are an arbitrary number of inactive firms. As said before, I only report the actions of the minimum number of firms required. In Sharkey (1982) quantity follows from demand. With differential pricing it is essential that the monopolist can use quantities to manipulate the group of consumers buying at the low price. Hence Sharkey's analysis is only appropriate under uniform pricing.

Under uniform pricing the possibilities of economies of scale are not fully exploited in equilibrium. The outcomes are therefore not Ramsey optimal, defined in Braeutigam (1989) as the prices that maximize the sum of consumer and producer surplus, subject to non-negativity of profits. Case (i) is inefficient because there is residual demand left and case (ii) is inefficient because by Assumption 1, one firm can produce output more efficiently than two.

The inefficiency of the outcomes of Proposition 1 prompts the question why economies of scale are not exploited. If firm 1 can set more than one price it may increase both output and profit. In some instances differential pricing may be legally prohibited. Also differential pricing can be excluded by assuming some form of arbitrage (see Braeutigam 1989). Since differential pricing is common practice and in addition the absence of duplication of fixed costs may induce welfare improvements, the question is legitimate.

\footnotetext{
${ }^{6}$ A special case is $\exists \mathrm{p}: \mathrm{ac}\left(\mathrm{d}(\mathrm{p})-\mathrm{q}^{*}\right)=\mathrm{p}$ and $\forall \mathrm{p}^{\prime} \neq \mathrm{p}: \mathrm{ac}\left(\mathrm{d}\left(\mathrm{p}^{\prime}\right)-\mathrm{q}^{*}\right)>\mathrm{p}^{\prime}$, in which case only three firms are needed to guarantee existence of a Nash equilibrium, since the 'residual' firm need not be disciplined, a case missed by Sharkey (1982).
} 


\section{Differential pricing}

Chander and Leruth (1989) provide two examples in order to demonstrate that a single firm can set two different prices for the same product without being interested in the profile or identity of the two groups of consumers. Setting two prices can be optimal, given technology and rationing. However, their examples are more suitable as an illustration of the smoothing out of congestion effects than of entry deterrence. I consider a situation where the low price is set to keep entrants out and the high price is set to generate a profit. Firm 1 simultaneously sets two prices and subsequently two quantities to the same group of consumers. The natural interpretation is that the quantity at the low price will be sold first after which consumers with sufficiently high reservation prices, that were not able to buy at the low price, buy at the high price. The justification for this interpretation is the fact that equilibria in the simultaneous game are equivalent to equilibria in a two-stage sequential game where firm 1 sets $\left(\mathrm{p}_{1}, \mathrm{q}_{1}\right)$ in the first stage, after which firm 2 sets $\left(\mathrm{p}_{2}, \mathrm{q}_{2}\right)$. In the second stage firm 1 sets $\left(\mathrm{p}_{1}^{\prime}, \mathrm{q}_{1}^{\prime}\right)$ and firm 2 reacts with $\left(p_{2}^{\prime}, q_{2}^{\prime}\right)$. The first-stage choices must be used to keep the entrant out and establishes firm 1 as the incumbent. The second-stage choices can then be used to exploit economies of scale (cf. Canoy 1993).

There are many examples of this strategy of "loss leading". For instance in the airline industry the first group of customers often pay a lower price than the last group of customers. Differential pricing is there to exploit economies of scale while at the same time entry is deterred. Setting a price that induces a loss on a submarket to lessen competition or force rivals to close down is forbidden in the US under the Robinson-Patman Act. A priori though, the effects of differential pricing on competition and welfare are unclear. I distinguish three cases.

1) Firms are not allowed to make a loss on a submarket (dumping). In other words, firms cannot sell a quantity $\mathrm{q}$ at a price $\mathrm{p}$ such that $\mathrm{p}-\mathrm{AC}(\mathrm{q})<0$.

2) Only the incumbent can engage in dumping.

3) All firms are allowed to engage in dumping.

It is important to distinguish between these subcases. For instance, case 1) must be an implicit assumption in Perry (1984), otherwise the proof of his Lemma 1 is flawed. Case 3) is implicit in Mandy (1992) and, although he considers second-degree price discrimination, I get the same type of result as he does.

\subsection{DUMPING IS PROHIBITED FOR ALL FIRMS}

I want to compare the equilibria under uniform pricing with the equilibria under differential pricing. I assume it is not possible to set more than two different prices. As I will specify below, in the welfare comparisons this assumption can become crucial. If a monopolist can set any number of prices (and 
quantities) it can extract more of the consumer surplus. It is important to observe the following.

\section{Observation 1}

Under differential pricing and subadditivity of the cost function, only one firm (firm 1) can set a positive quantity in equilibrium. Suppose this firm maximizes its profit subject to an entry-deterring constraint. To establish the optimal prices and quantities of firm 1 as equilibrium prices and quantities, there need to be sufficient potential entrants with entry-threatening prices. Given these optimal prices and quantities, the potential entrants can do no better than threaten to enter. Similarly, the incumbent can do no better than to optimize given that entry is threatening, since accommodating entry is never profitable in this model.

It will appear that under differential pricing consumers can be better off, because more consumers are able to buy the product. Firms can be better off because total costs are lower. The easiest way to think about this is to see a firm as the sum of two subfirms, both setting a price and a quantity. Contingent demand of firm $i$ is obtained by adding up contingent demands of both subfirms. Let $p_{1}^{L}$ be the lowest price of firm 1 and $p_{1}^{H}$ be the highest and let $q_{1}^{L}$ and $q_{1}^{H}$ be the corresponding quantities, i.e. $q_{1}^{L}$ is the quantity the monopolist furnishes at price $\mathrm{p}_{1}^{\mathrm{L}}$. Denote the contingent demand of the subfirms with $\mathrm{D}_{\mathrm{iL}}\left(\mathrm{p}_{\mathrm{i}}^{\mathrm{L}}, \mathrm{p}_{\mathrm{i}}^{\mathrm{H}}, \mathrm{P}_{-\mathrm{i}} ; \mathrm{Q}_{-\mathrm{iL}}\right)$ for the low price and $\mathrm{D}_{\mathrm{iH}}\left(\mathrm{p}_{\mathrm{i}}^{\mathrm{L}}, \mathrm{p}_{\mathrm{i}}^{\mathrm{H}}, \mathrm{P}_{-\mathrm{i}} ; \mathrm{Q}_{-\mathrm{H}}\right)$ for the high price. Let $\mathrm{D}_{\mathrm{iL}}()+.\mathrm{D}_{\mathrm{iH}}(.) \equiv \mathrm{D}_{\mathrm{i}}\left(\mathrm{P} ; \mathrm{Q}_{\mathrm{i}}\right)$, then the profit becomes:

$$
\begin{aligned}
\pi_{\mathrm{i}}(\mathrm{P} ; \mathrm{Q}) & =\mathrm{p}_{\mathrm{i}}^{\mathrm{L}} \mathrm{q}_{\mathrm{i}}^{\mathrm{L}}+\mathrm{p}_{\mathrm{i}}^{\mathrm{H}} \mathrm{q}_{\mathrm{i}}^{\mathrm{H}}-\mathrm{C}\left(\mathrm{q}_{\mathrm{i}}^{\mathrm{L}}+\mathrm{q}_{\mathrm{i}}^{\mathrm{H}}\right) & & \text { for } 0<\mathrm{q}_{\mathrm{i}}^{\mathrm{L}}+\mathrm{q}_{\mathrm{i}}^{\mathrm{H}} \leq \mathrm{D}_{\mathrm{i}}\left(\mathrm{P} ; \mathrm{Q}_{\mathrm{i}}\right) \\
& =0 & & \text { otherwise. }
\end{aligned}
$$

From Proposition 1(i) it follows that if $p<A C\left(D(p)-q^{*}\right)$ for all $p$ and $D\left(p^{*}\right)-q^{*}>0$, firm 1 can set its high price without being bothered by competitors. The optimal high price, denoted as $\hat{\mathrm{p}}$, is obtained as follows:

$$
\hat{\mathrm{p}}\left(\mathrm{q}_{1}^{\mathrm{L}}\right)=\operatorname{argmax}_{\mathrm{p}}\left\{\mathrm{p}^{*} \mathrm{q}_{1}^{\mathrm{L}}+\mathrm{p}\left[\mathrm{D}(\mathrm{p})-\mathrm{q}_{1}^{\mathrm{L}}\right]-\mathrm{C}[\mathrm{D}(\mathrm{p})]\right\}
$$

Since firm 1 produces both quantities, $\hat{\mathrm{p}}$ is obtained by maximizing total profit given $\mathrm{p}^{*}$ and $\mathrm{q}^{*}$. The high quantity $\mathrm{q}_{1}^{\mathrm{H}}$ is equal to residual demand (for a proof, see Lemma 1, Appendix). Setting both $\mathrm{p}^{*}$ and $\hat{\mathrm{p}}\left(\mathrm{q}^{*}\right)$ makes firm 1 better off compared to uniform pricing, the other firms are indifferent and more consumers can buy the product. Differential pricing not only improves social welfare here, but even leads to a Pareto improvement.

If there is a $p$ such that $p \geq A C\left(D(p)-q^{*}\right)$, firm 1 can engage in differential pricing as well. Since the cost function is subadditive on the relevant range, firm 1 can produce the residual demand cheaper than other firms. By Observation 1 firm 1 maximizes its profit under an entry-deterrence constraint:

$$
\begin{array}{ll}
\hat{\mathrm{p}}=\operatorname{argmax} \mathrm{p} & \left\{\mathrm{p}^{*} \mathrm{q}^{*}+\mathrm{p}\left[\mathrm{D}(\mathrm{p})-\mathrm{q}^{*}\right]-\mathrm{C}[\mathrm{D}(\mathrm{p})]\right\} \\
& \text { s.t. } \mathrm{p}^{*}<\mathrm{p} \leq \mathrm{p}^{\mathrm{R}}\left(\mathrm{q}^{*}\right)
\end{array}
$$

As in (6), in the optimum $\mathrm{q}_{1}^{\mathrm{H}}$ must be equal to residual demand (proof Lemma 1, Appendix). 
Proposition 2 shows that a unique equilibrium exists for both cases and the incumbent firm 1 makes a positive profit. For uniqueness of the equilibrium I need the following additional assumptions on the cost and demand functions:

\section{Assumption 3 \\ $\mathrm{C}^{\prime \prime}(\mathrm{q})>0$. \\ Assumption 4 \\ $\mathrm{pD}(\mathrm{p})$ is concave.}

\section{Proposition 2}

Under Assumptions 1-4:

(i) If for all $\mathrm{p}$ : $\mathrm{p}<\mathrm{AC}\left(\mathrm{D}(\mathrm{p})-\mathrm{q}^{*}\right)$ and $\mathrm{D}\left(\mathrm{p}^{*}\right)-\mathrm{q}^{*}>0$, then: $\left(\mathrm{p}_{1}^{\mathrm{L}}, \mathrm{p}_{1}^{\mathrm{H}}, \mathrm{p}_{2}^{\mathrm{L}}, \mathrm{p}_{2}^{\mathrm{H}} ; \mathrm{q}_{1}^{\mathrm{L}}, \mathrm{q}_{1}^{\mathrm{H}}, \mathrm{q}_{2}^{\mathrm{L}}, \mathrm{q}_{2}^{\mathrm{H}}\right)=$ $\left(\mathrm{p}^{*}, \hat{\mathrm{p}}\left(\mathrm{q}^{*}\right), \mathrm{p}^{*}, \hat{\mathrm{p}}\left(\mathrm{q}^{*}\right) ; \mathrm{q}^{*}, \mathrm{q}^{\mathrm{R}}\left(\hat{\mathrm{p}}\left(\mathrm{q}^{*}\right), \mathrm{q}^{*}\right), 0,0\right)$ is the unique equilibrium and $\pi_{1}()>$.0 .

(ii) If there is a $\mathrm{p}$ such that $\mathrm{p} \geq \mathrm{AC}\left(\mathrm{D}(\mathrm{p})-\mathrm{q}^{*}\right)$, then: $\left(\mathrm{p}_{1}^{\mathrm{L}}, \mathrm{p}_{1}^{\mathrm{H}}, \mathrm{p}_{2}^{\mathrm{L}}, \mathrm{p}_{2}^{\mathrm{H}} ; \mathrm{q}_{1}^{\mathrm{L}}, \mathrm{q}_{1}^{\mathrm{H}}, \mathrm{q}_{2}^{\mathrm{L}}, \mathrm{q}_{2}^{\mathrm{H}}\right)=$ $\left(\mathrm{p}^{*}, \hat{\mathrm{p}}, \mathrm{p}^{*}, \mathrm{p}^{\mathrm{R}}\left(\mathrm{q}^{*}\right) ; \mathrm{q}^{*}, \mathrm{q}^{\mathrm{R}}\left(\hat{\mathrm{p}} \mathrm{q}^{*}\right), 0,0\right)$ is the unique equilibrium and $\pi_{1}()>$.0 .

The equilibria under differential pricing are Pareto superior to the equilibria under uniform pricing in case (i) and also in case (ii) if $\hat{\mathrm{p}}=\mathrm{p}^{\mathrm{R}}\left(\mathrm{q}^{*}\right)$. In (i) still $\mathrm{q}^{*}$ consumers pay $\mathrm{p}^{*}$, more profit is made and more consumers are served. In case (ii), if $\hat{p}=p^{R}\left(q^{*}\right)$, the same prices and quantities are set, but there is an efficiency gain because the incumbent produces both quantities. In case (i) the high price of firm 1 cannot be undercut, because firm 2 cannot serve residual demand.

The result from the literature which says that in order for differential pricing to be welfare improving it has to induce an increase in output (Tirole 1989), does not necessary hold here due to the U-shaped AC curves. The Pareto improvement in case (i) is independent of the assumption that only two prices can be set. Any schedule that includes $\left(\mathrm{p}^{*}, \mathrm{q}^{*}\right)$ is Pareto superior to the equilibrium in Proposition 1(i). In case (ii) the assumption can be restrictive. Suppose that three prices are allowed. Firm 1 sets $\left(\mathrm{p}^{*}, \mathrm{q}^{*}\right)$ and it uses a second quantity to shift the residual demand curve of the other firms to the left of the AC curve, such that it becomes the uncontested monopolist on the residual market. It is not clear whether the efficiency gain (in comparison with uniform pricing) outweighs the loss of consumer surplus in that case. The fact that differential pricing can lead to a Pareto improvement acknowledges a result of Thisse \& Vives (1988), albeit in a different setting, that contrary to general belief uniform pricing is not evidence of a more competitive environment.

At this point it is appropriate to compare Proposition 2 with Theorem 2 of Perry (1984). Perry states that the incumbent chooses prices and quantities such that it shifts the residual demand of the entrants to the left of the $\mathrm{AC}$ curve, so that it effectively deters entry. Of all prices and quantities that achieve this deterrence, the incumbent then chooses the optimal ones and thereby realizes a positive 
profit. However, in setting $\mathrm{p}_{1}^{\mathrm{L}}=\mathrm{p}^{*}$ the incumbent firm 1 only succeeds in deterring entry if dumping is forbidden. Therefore this assumption must have been implicit in Perry's paper.

The equilibria of Proposition 1 were not Ramsey optimal. Although differential pricing can improve welfare, it is not true that the outcomes are Ramsey optimal. For any given total quantity q, welfare W is equal to:

$$
W=\int_{0}^{q} D^{-1}(q) d z-p q+\pi=\int_{0}^{q} D^{-1}(q) d z-C(q) .
$$

Observe that, for given q, welfare is independent of the prices. This is so because a change in the price does not necessarily lead to a change in the total quantity. This effect does not appear in models where the quantity is equal to demand. The only requirement is that prices are feasible and that the profit is non-negative. This means that Ramsey prices are not uniquely determined. Maximizing W yields the Ramsey optimal quantity $\mathrm{q}^{\mathrm{RAM}}$ as the solution of: $\mathrm{D}^{-1}(\mathrm{q})=\mathrm{C}^{\prime}(\mathrm{q})$. Both a uniform price and differential prices can be Ramsey optimal as long as the total quantity is equal to the optimal quantity.

\section{Welfare Result 1}

Let $D\left(p^{*}\right)>q^{*}$. Under Assumptions 1-4 the equilibria of Proposition 2 are not Ramsey optimal and the total quantity is lower than $\mathrm{q}^{\mathrm{RAM}}$.

\section{Proof}

In Proposition 2 the total quantity is equal to $q=D\left(p_{1}^{H}\right)$. By Lemma 1 , in equilibrium: $q_{1}^{H}=D\left(p_{1}^{H}\right)-q^{*}$. Instead of solving (6) for $\mathrm{p}_{1}^{\mathrm{H}}$ given $\mathrm{q}_{1}^{\mathrm{H}}=\mathrm{D}\left(\mathrm{p}_{1}^{\mathrm{H}}\right)-\mathrm{q}^{*}$, one can solve $(6)$ for $\mathrm{q}_{1}^{\mathrm{H}}$ given $\mathrm{p}_{1}^{\mathrm{H}}=\mathrm{D}^{-1}\left(\mathrm{q}^{*}+\mathrm{q}_{1}^{\mathrm{H}}\right)$. Or:

$$
\operatorname{Max}_{q_{1}^{\mathrm{H}}} \mathrm{p}^{*} \mathrm{q}^{*}+\mathrm{D}^{-1}\left(\mathrm{q}^{*}+\mathrm{q}_{1}^{\mathrm{H}}\right) \mathrm{q}_{1}^{\mathrm{H}}-\mathrm{C}\left(\mathrm{q}^{*}+\mathrm{q}_{1}^{\mathrm{H}}\right) \text {. }
$$

The FOC is:

$$
\mathrm{D}^{-1}\left(\mathrm{q}^{*}+\mathrm{q}_{1}^{\mathrm{H}}\right)+\left(\mathrm{D}^{-1}\right)^{\prime} \mathrm{q}_{1}^{\mathrm{H}}-\mathrm{C}^{\prime}\left(\mathrm{q}^{*}+\mathrm{q}_{1}^{\mathrm{H}}\right)=0
$$

Suppose $\mathrm{q}^{*}+\mathrm{q}_{1}^{\mathrm{H}}=\mathrm{q}^{\mathrm{RAM}}$, then $\left(\mathrm{D}^{-1}\right)^{\prime} \mathrm{q}_{1}^{\mathrm{H}}=0$, implying $\mathrm{q}_{1}^{\mathrm{H}}=0$ and $\mathrm{q}^{\mathrm{RAM}}=\mathrm{q}^{*}$ contradicting $\mathrm{D}\left(\mathrm{p}^{*}\right)>\mathrm{q}^{*}$. Since $\left(D^{-1}\right)^{\prime} q_{1}^{H}<0$ and, by Assumption 3, $D^{-1}(q)-C^{\prime}(q)$ is decreasing in $q$, it follows that in equilibrium $\mathrm{q}^{*}+\mathrm{q}_{1}^{\mathrm{H}}<\mathrm{q}^{\mathrm{RAM}}$. The same argument holds for the solution of (7).

This result is independent of the assumption that only two prices can be set.

\subsection{ONLY DUMPING BY THE INCUMBENT IS ALLOWED}

Suppose now that only dumping by the incumbent is allowed. In order to prevent entry, the incumbent still has to set $\mathrm{p}_{1}^{\mathrm{L}}=\mathrm{p}^{*}$, but it has the possibility to shift customers from the low price market to the high price market. To prevent an open-set problem, I assume that entry occurs if firms can achieve a strictly positive profit. 
Firm 1 can manipulate with quantity, such that it increases its profit while still deterring entry. The optimization problem for the incumbent becomes:

$$
\begin{aligned}
& \max \mathrm{p}_{1}^{\mathrm{H}}, \mathrm{q}_{1}^{\mathrm{L}}, \mathrm{q}_{1}^{\mathrm{H}} \quad \pi_{1} \equiv \mathrm{p}^{*} \mathrm{q}_{1}^{\mathrm{L}}+\mathrm{p}_{1}^{\mathrm{H}} \mathrm{q}_{1}^{\mathrm{H}}-\mathrm{C}\left(\mathrm{q}_{1}^{\mathrm{L}}+\mathrm{q}_{1}^{\mathrm{H}}\right), \\
& \text { s.t. (i) } \quad \forall \mathrm{p} \leq \mathrm{p}_{1}^{\mathrm{H}}: \mathrm{AC}\left(\mathrm{D}(\mathrm{p})-\mathrm{q}_{1}^{\mathrm{L}}\right) \geq \mathrm{p} \\
& \text { (ii) } \quad \mathrm{q}^{\mathrm{R}}\left(\mathrm{p}^{*}, \mathrm{q}^{*}\right) \leq \mathrm{q}_{\mathrm{I}}^{\mathrm{L}}
\end{aligned}
$$

Since dumping by the other firms is not allowed, firm 1 always sets $\mathrm{p}^{*}$ as the lowest price. The restrictions are entry-deterrence conditions. By (9)-(i) there is no price lower than or equal to $p_{1}^{H}$ at which entrants can profitably sell residual demand. Restriction (9)-(ii) prevents entrants from selling $\mathrm{q}^{*}$ at any price. If residual demand is higher than $\mathrm{q}^{*}$, there exists an $\varepsilon>0$ such that an entrant can undercut $\mathrm{p}_{1}^{\mathrm{H}}$ with $\mathrm{p}^{*}+\varepsilon<\mathrm{p}_{1}^{\mathrm{H}}$, set $\left(\mathrm{p}^{*}+\varepsilon ; \mathrm{q}^{*}\right)$ and get a positive profit. Both restrictions provide a lower bound for $\mathrm{q}_{1}^{\mathrm{L}}$. The program has to be solved with the Kuhn-Tucker technique, which seems hard with three variables, general cost and demand functions and an infinite number of constraints. However, the following definition can be used to eliminate a lot of cases.

\section{Definition 3}

Denote $(\widetilde{p}, \widetilde{q})$ as the price-quantity pair that satisfies:

(i) $\quad \mathrm{AC}\left(\mathrm{q}^{\mathrm{R}}(\widetilde{\mathrm{p}}, \widetilde{\mathrm{q}})\right)=\widetilde{\mathrm{p}}$ and

(ii) $\forall \mathrm{p}^{\prime} \neq \widetilde{\mathrm{p}}: \operatorname{AC}\left(\mathrm{q}^{\mathrm{R}}\left(\mathrm{p}^{\prime}, \widetilde{\mathrm{q}}\right)\right)>\mathrm{p}^{\prime}$.

The AC curve has derivative 0 at $\mathrm{q}=\mathrm{q}^{*}$ and (by Assumption 1(iii)) minus infinity at $\mathrm{q}=0$. To guarantee that there exists a quantity $\mathrm{q}<\mathrm{q}^{*}$ such that residual demand is tangent to the AC curve, I need an additional Assumption on demand function:

\section{Assumption 5}

$\left(\mathrm{D}^{-1}\right)^{\prime \prime}(\mathrm{q})<\mathrm{AC}^{\prime \prime}(\mathrm{q})$.

Assumption 5 says that the (inverse) demand function is less convex than the AC curve. From this and Assumption 1(ii) it follows that there exists exactly one pair $(\widetilde{\mathrm{p}}, \widetilde{\mathrm{q}})$ that satisfies Definition 3. From Definition 3(i) it follows immediately that (9)-(ii) is satisfied for $\mathrm{q}_{1}^{\mathrm{L}}=\widetilde{\mathrm{q}} \cdot{ }^{7}$ Choosing $\mathrm{q}_{1}^{\mathrm{L}}=\widetilde{\mathrm{q}}$ means that other firms cannot set a profitable quantity at any price and firm 1 becomes the uncontested monopolist on the residual market (see figure 2). At $\widetilde{\mathrm{q}}$ condition (9)-(i) is never binding since it is satisfied for all prices. It can be readily verified that choosing $\mathrm{q}_{1}^{\mathrm{L}}>\widetilde{\mathrm{q}}$ is not a profit maximizing

${ }^{7} \widetilde{\mathrm{p}}$ and $\widetilde{\mathrm{q}}$ can be found as follows: solve $\partial \mathrm{d}^{-1}(\mathrm{q}) / \partial \mathrm{q}=\partial \mathrm{ac}(\mathrm{q}) / \partial \mathrm{q}$, call the solution $\mathrm{q}^{\prime}$. Then $\widetilde{\mathrm{p}}$ and $\widetilde{\mathrm{q}}$ are given by: $\widetilde{\mathrm{p}}=\mathrm{ac}\left(\mathrm{q}^{\prime}\right)$ and $\widetilde{\mathrm{q}}=\mathrm{d}(\widetilde{\mathrm{p}})-\mathrm{q}^{\prime}$. 
strategy. ${ }^{8}$ Also if firm 1 sets $\mathrm{q}_{1}^{\mathrm{L}}=\widetilde{\mathrm{q}}$, the high quantity $\mathrm{q}_{1}^{\mathrm{H}}$ is equal to residual demand (for a proof see Lemma 2, Appendix). So if firm 1 sets $\mathrm{q}_{1}^{\mathrm{L}}=\widetilde{\mathrm{q}}$ the program (9) is simplified into a one-dimensional maximization problem: find the optimal $p_{1}^{H}$ that satisfies the constraints given $\left(p_{1}^{L}, q_{1}^{L}, q_{1}^{H}\right)=$ $\left(\mathrm{p}^{*}, \widetilde{\mathrm{q}}, \mathrm{q}^{\mathrm{R}}\left(\mathrm{p}^{*}, \widetilde{\mathrm{q}}\right)\right)$. Let me call this program $\mathrm{A}$, with solution $\mathrm{A}$ :

\section{PROGRAM A}

$\max \mathrm{p}_{1}^{\mathrm{H}} \quad \pi_{1} \equiv \mathrm{p} * \widetilde{\mathrm{q}}+\mathrm{p}_{1}^{\mathrm{H}}\left(\mathrm{D}\left(\mathrm{p}_{1}^{\mathrm{H}}\right)-\widetilde{\mathrm{q}}\right)-\mathrm{C}\left(\mathrm{D}\left(\mathrm{p}_{1}^{\mathrm{H}}\right)\right)$

If firm 1 sets any lower quantity than $\widetilde{q}$, there is entry danger, which forces firm 1 to set $p_{1}^{H}=p^{R}\left(q_{1}^{L}\right)$ in order to satisfy constraint 8-(i). ${ }^{9}$ Suppose firm 1 sets $\mathrm{q}_{1}^{\mathrm{L}}<\widetilde{\mathrm{q}}$ and consequently $\mathrm{p}_{1}^{\mathrm{H}}=\mathrm{p}^{\mathrm{R}}\left(\mathrm{q}_{1}^{\mathrm{L}}\right)$. Now the program (9) is two-dimensional. It cannot be proved that the program has an interior solution in this case. ${ }^{10}$ Let me call this program $B$ :

\section{PROGRAM B}

$$
\begin{array}{ll}
\max _{\mathrm{q}_{1}^{\mathrm{L}}, \mathrm{q}_{1}^{\mathrm{H}}} & \pi_{1} \equiv \mathrm{p}^{*} \mathrm{q}_{1}^{\mathrm{L}}+\mathrm{p}^{\mathrm{R}}\left(\mathrm{q}_{1}^{\mathrm{L}}\right) \mathrm{q}_{1}^{\mathrm{H}}-\mathrm{C}\left(\mathrm{q}_{1}^{\mathrm{L}}+\mathrm{q}_{1}^{\mathrm{H}}\right) \\
\text { s.t. } & \mathrm{q}^{\mathrm{R}}\left(\mathrm{p}^{*}, \mathrm{q}^{*}\right) \leq \mathrm{q}_{1}^{\mathrm{L}} \\
& \mathrm{q}_{1}^{\mathrm{L}} \leq \widetilde{\mathrm{q}} \\
& \mathrm{q}_{1}^{\mathrm{H}} \leq \mathrm{D}\left(\mathrm{p}_{\mathrm{R}}\left(\mathrm{q}_{1}^{\mathrm{H}}\right)-\mathrm{q}_{1}^{\mathrm{H}}\right)
\end{array}
$$

If program B has a solution with $\mathrm{q}_{1}^{\mathrm{L}}<\widetilde{\mathrm{q}}, \mathrm{I}$ call it solution B. In order to establish an equilibrium, profits at solutions A and B should be compared. Whichever solution yields the highest profit will be realized in an equilibrium.

\section{Proposition 3}

Under Assumptions 1-4 and if only dumping by the incumbent is allowed, in GAME PQ the following holds:

(i) If for all $\left(\mathrm{q}_{1}^{\mathrm{L}}, \mathrm{q}_{1}^{\mathrm{H}}\right)$ with $\mathrm{q}_{1}^{\mathrm{L}}<\widetilde{\mathrm{q}}: \pi_{1}\left(\mathrm{p}^{*}, \mathrm{p}^{\mathrm{R}}\left(\mathrm{q}_{1}^{\mathrm{L}}\right) ; \mathrm{q}_{1}^{\mathrm{L}}, \mathrm{q}_{1}^{\mathrm{H}}\right) \leq \pi_{1}\left(\mathrm{p}^{*}, \hat{\mathrm{p}}(\widetilde{\mathrm{q}}) ; \widetilde{\mathrm{q}}, \mathrm{q}^{\mathrm{R}}(\hat{\mathrm{p}}(\widetilde{\mathrm{q}}), \widetilde{\mathrm{q}})\right)$, then the unique equilibrium is: $\left.\left(\mathrm{p}_{1}^{\mathrm{L}}, \mathrm{p}_{1}^{\mathrm{H}}, \mathrm{p}_{2}^{\mathrm{L}}, \mathrm{p}_{2}^{\mathrm{H}} ; \mathrm{q}_{1}^{\mathrm{L}}, \mathrm{q}_{1}^{\mathrm{H}}, \mathrm{q}_{2}^{\mathrm{L}}, \mathrm{q}_{2}^{\mathrm{H}}\right)=\left(\mathrm{p}^{*}, \hat{\mathrm{p}}(\widetilde{\mathrm{q}}), \mathrm{p}^{*}, \hat{\mathrm{p}} \widetilde{\mathrm{q}}\right) ; \widetilde{\mathrm{q}}, \mathrm{q}^{\mathrm{R}}(\hat{\mathrm{p}}(\widetilde{\mathrm{q}}), \widetilde{\mathrm{q}}), 0,0\right)$.

(ii) Let there be a $\left(\mathrm{q}_{1}^{\mathrm{L}}, \mathrm{q}_{1}^{\mathrm{H}}\right)$ with $\mathrm{q}_{1}^{\mathrm{L}}<\widetilde{\mathrm{q}}$ such that $\pi_{1}\left(\mathrm{p}^{*}, \mathrm{p}^{\mathrm{R}}\left(\mathrm{q}_{1}^{\mathrm{L}}\right) ; \mathrm{q}_{1}^{\mathrm{L}}, \mathrm{q}_{1}^{\mathrm{H}}\right)>\pi_{1}\left(\mathrm{p}^{*}, \hat{\mathrm{p}} \mathrm{q}(\widetilde{\mathrm{q}}) ; \widetilde{\mathrm{q}}, \mathrm{q}^{\mathrm{R}}(\hat{\mathrm{p}}(\widetilde{\mathrm{q}}), \widetilde{\mathrm{q}})\right)$ and

\footnotetext{
${ }^{8}$ To see this one should realize that entry is already deterred at $\widetilde{q}$, so that setting a higher $q_{1}^{L}$ only reduces profit, since $q_{1}^{L}$ is sold at $\mathrm{p}^{*}$.

${ }^{9}$ One can show by using the same method as in Lemma 2 that $p<p^{R}\left(q_{1}^{L}\right)$ is not feasible in the optimum.

${ }^{10}$ It is not clear whether the second-order conditions are satisfied. There is ambiguity in signs of the determinants of the Hessian.
} 
there is no $\left(\mathrm{q}_{1}^{\mathrm{L} \prime}, \mathrm{q}_{1}^{\mathrm{H} \prime}\right)$ giving a higher profit, then in an equilibrium:

$\left(\mathrm{p}_{1}^{\mathrm{L}}, \mathrm{p}_{1}^{\mathrm{H}}, \mathrm{p}_{2}^{\mathrm{L}}, \mathrm{p}_{2}^{\mathrm{H}} ; \mathrm{q}_{1}^{\mathrm{L}}, \mathrm{q}_{1}^{\mathrm{H}}, \mathrm{q}_{2}^{\mathrm{L}}, \mathrm{q}_{2}^{\mathrm{H}}\right)=\left(\mathrm{p}^{*}, \mathrm{p}_{1}^{\mathrm{H}}, \mathrm{p}^{*}, \mathrm{p}^{\mathrm{R}}\left(\mathrm{q}_{1}^{\mathrm{L}}\right) ; \mathrm{q}_{1}^{\mathrm{L}}, \mathrm{q}_{1}^{\mathrm{H}}, 0,0\right)$.

It can be useful for the incumbent to transfer consumers from the low price to the high price, while still preventing entry. This gives the incumbent a higher profit than in Proposition 2. It is not possible to provide explicit conditions for case (i) or case (ii) to hold, one of the reasons for this being that $\widetilde{q}$ is implicitly defined.

Let me compare the welfare of Proposition 2(i) and Proposition 3(i). I prove that the equilibrium high price is decreasing in $q_{1}^{\mathrm{L}}$, so that total quantity (and therefore welfare) of Proposition 2(i) is higher than that of Proposition 3(i).

\section{Welfare Result 2}

The equilibrium of Proposition 3(i) leads to a lower welfare than the equilibrium of Proposition 2(i). Proof

Notice that $\widetilde{\mathrm{q}} \leq \mathrm{q}^{*}$, since firm 1 has no incentive to sell more than $\mathrm{q}^{*}$ at the low price. Since in both Proposition 2(i) and Proposition 3(i) total quantity is equal to $\mathrm{D}\left(\mathrm{p}_{1}^{\mathrm{H}}\right)$, I only have to prove that $\hat{p}(\widetilde{q})>\widehat{p}\left(q^{*}\right)$, i.e. I have to prove that $\hat{p}\left(q_{1}^{L}\right)$ is decreasing in $q_{1}^{L} \cdot \hat{p}\left(q_{1}^{L}\right)$ is the solution of:

$$
\max _{\mathrm{p}_{1}^{\mathrm{H}}} \pi=\mathrm{p}_{1}^{\mathrm{L}} \mathrm{q}_{1}^{\mathrm{L}}+\mathrm{p}_{1}^{\mathrm{H}}\left(\mathrm{D}\left(\mathrm{p}_{1}^{\mathrm{H}}\right)-\mathrm{q}_{1}^{\mathrm{L}}\right)-\mathrm{C}\left(\mathrm{D}\left(\mathrm{p}_{1}^{\mathrm{H}}\right)\right)
$$

Using the Implicit Function Theorem to evaluate $\mathrm{d} \hat{\mathrm{p}} / \mathrm{dq}_{1}^{\mathrm{L}}$ gives:

$$
\mathrm{d} \hat{\mathrm{p}} / \mathrm{dq} \mathrm{q}_{1}^{\mathrm{L}}=-\left(\partial \pi^{\prime} / \partial \mathrm{q}_{\mathrm{L}}^{\mathrm{L}}\right) /\left(\partial \pi^{\prime} / \partial \mathrm{p}_{1}^{\mathrm{H}}\right)
$$

Since by the second order condition $\left(\partial \pi^{\prime} / \partial \mathrm{p}_{1}^{\mathrm{H}}\right)<0$, it remains to be shown that $\partial \pi^{\prime} / \partial \mathrm{q}_{1}^{\mathrm{L}}<0$. Now:

$$
\pi^{\prime}=\mathrm{D}\left(\mathrm{p}_{1}^{\mathrm{H}}\right)-\mathrm{q}_{1}^{\mathrm{L}}+\mathrm{D}^{\prime}\left[\mathrm{p}_{1}^{\mathrm{H}}-\mathrm{C}^{\prime}\left(\mathrm{D}\left(\mathrm{p}_{1}^{\mathrm{H}}\right)\right)\right]
$$

so that clearly $\partial \pi^{\prime} / \partial \mathrm{q}_{1}^{\mathrm{L}}<0$.

The result implies that allowing the incumbent to dump leads to a welfare loss. In Proposition 3(ii) $\mathrm{q}_{1}^{\mathrm{L}}<\widetilde{\mathrm{q}}$ so that welfare is even lower. The comparison with Proposition 1(i) leads to ambiguity. It depends on whether $\mathrm{D}\left(\mathrm{p}_{1}^{\mathrm{H}}\right)$ is smaller or bigger than $\mathrm{q}^{*}$. The same holds for the comparison with Proposition 1(ii). It depends whether the efficiency gain is outweighed by the lower quantity that is sold (see also section 4). If the assumption that only two prices can be set is dropped, the result would be even more favourable for the equilibrium of Proposition 2. In Proposition 3(i) the residual market is bigger and can be better exploited if more prices can be set.

\subsection{ALL FIRMS ARE ALLOWED TO ENGAGE IN DUMPING}

If firm 1 maximizes total profit it may transfer consumers from the low price to the high price. But 
under free entry, potential entrants can also engage in differential pricing, such that positive profits can be competed away. This corresponds to Mandy's (1991) main result. The proof here is almost trivial, although it is based on the same basic intuition. Any set of clients from which a positive profit can be obtained can be served by an undercutting rival, approximating the (positive) profit.

\section{Proposition 4}

Under Assumptions 1-2, if all firms are allowed to engage in dumping, no positive profit can be realized in an equilibrium.

Proof

Suppose firm 1 sets $\left(\mathrm{p}_{1}^{\mathrm{L}}, \mathrm{p}_{1}^{\mathrm{H}}\right)$ in stage 1 and makes a positive profit. There exists an $\varepsilon>0$ such that firm 2 can set $\left(\mathrm{p}_{1}^{\mathrm{L}}-\varepsilon, \mathrm{p}_{1}^{\mathrm{H}}-\varepsilon\right)$ in stage 1 , shutting down firm 1 , while making a positive profit.

Since dumping is unrestricted the usual undercutting argument applies and, contrary to Perry's result, no positive profit is possible. Finally, I show that even if all firms can set prices below average costs, an equilibrium exists. The idea is to take the equilibrium of Proposition 3 and shift $p_{1}^{L}$ downwards such that profits become zero. For reasons of exposition I assume now that cost and demand are such that Proposition 3(i) applies. If Proposition 3(ii) applies, the result will be analogous, i.e. $p_{1}^{L}$ is lowered until profits become zero. Define $\underline{p}$ as the price at which: $\pi_{1}\left(\mathrm{p}, \hat{\mathrm{p}}(\widetilde{\mathrm{q}}) ; \widetilde{\mathrm{q}}, \mathrm{q}^{\mathrm{R}}(\hat{\mathrm{p}}(\widetilde{\mathrm{q}}), \widetilde{\mathrm{q}})\right)=0$.

\section{Proposition 5}

Under Assumptions 1-4, if all firms are allowed to engage in dumping and Proposition 3-(i) applies, there exists a unique equilibrium with $\left(\mathrm{p}_{1}^{\mathrm{L}}, \mathrm{p}_{1}^{\mathrm{H}}, \mathrm{p}_{2}^{\mathrm{L}}, \mathrm{p}_{2}^{\mathrm{H}} ; \mathrm{q}_{1}^{\mathrm{L}}, \mathrm{q}_{1}^{\mathrm{H}}, \mathrm{q}_{2}^{\mathrm{L}}, \mathrm{q}_{2}^{\mathrm{H}}\right)=\left(\mathrm{p}, \hat{\mathrm{p}}(\widetilde{\mathrm{q}}), \mathrm{p}, \hat{\mathrm{p}}(\widetilde{\mathrm{q}}) ; \widetilde{\mathrm{q}}, \mathrm{q}^{\mathrm{R}}(\hat{\mathrm{p}}(\widetilde{\mathrm{q}}), \widetilde{\mathrm{q}}), 0,0\right)$.

Proof

Take Proposition 3-(i). Let firm 1 decrease the low price to $\mathrm{p}$. In order to enter, a firm has to undercut $\mathrm{p}$. Since $\widetilde{\mathrm{q}}$ and $\hat{\mathrm{p}}$ are chosen optimally and independent of $\mathrm{p}_{1}^{\mathrm{L}}$, an undercutting entrant cannot achieve a non-negative profit. By Proposition 4 firm 1 cannot increase its profit, therefore $\left(\mathrm{p}_{1}^{\mathrm{L}}, \mathrm{p}_{1}^{\mathrm{H}}, \mathrm{p}_{2}^{\mathrm{L}}, \mathrm{p}_{2}^{\mathrm{H}} ; \mathrm{q}_{1}^{\mathrm{L}}, \mathrm{q}_{1}^{\mathrm{H}}, \mathrm{q}_{2}^{\mathrm{L}}, \mathrm{q}_{2}^{\mathrm{H}}\right)=\left(\mathrm{p}, \hat{\mathrm{p}}(\widetilde{\mathrm{q}}), \mathrm{p}, \hat{\mathrm{p}}(\widetilde{\mathrm{q}}) ; \widetilde{\mathrm{q}}, \mathrm{q}^{\mathrm{R}}(\hat{\mathrm{p}}(\widetilde{\mathrm{q}}), \widetilde{\mathrm{q}}), 0,0\right)$ is a unique equilibrium.

It is remarkable that in Proposition 5 it is not excluded that firm 1 has to drop $p_{1}^{\mathrm{L}}$ such that it becomes negative (!), which has the following interpretation. Market conditions may be such that the only way to keep entrants out in an equilibrium, requires a firm to engage in a stunt. The first 100 candies are distributed for free and the children get an extra balloon with the candy. The rest is sold at higher prices, which cannot be undercut due to economies of scale. If the firm does not perform this stunt it can be kicked out of the market by a rival which does. Interestingly, although the firm's profit becomes zero, welfare is not affected. This also shows that a higher profit does not necessarily imply a lower welfare. 


\section{Welfare Result 3}

The equilibria of Proposition 5 lead to the same welfare as the equilibria of Proposition 3.

Proof

Follows from the fact that the total quantity of Proposition 5 is equal to the total quantity of Proposition 3.

This result maintains to hold if more than two prices are allowed.

\section{An example}

In this section I will look at numerical examples in order to demonstrate the welfare effects. Assume demand is linear. I considered both quadratic $\mathrm{AC}$ functions and cost functions of the type $\mathrm{F}+\mathrm{Aq}^{2}$. Since they led to the same qualitative outcomes, I will only look at quadratic AC functions here. They violate Assumption 1(ii), but in order to restore feasibility it is possible to define a hyperbolic function for $0<\mathrm{q}<\varepsilon$, with $\varepsilon$ small, and a quadratic function for $\mathrm{q} \geq \varepsilon$. Assumption 1(ii) was only made to guarantee the existence of $\widetilde{q}$, so that I choose parameters such that $\widetilde{q}$ exists. Define the welfare that belongs to Proposition $i$ with $W_{i}$ for $i=1,2,3$. I do not consider $W_{5}$ because $W_{5}=W_{3}$.

$$
\begin{array}{ll}
\mathrm{D}(\mathrm{p})=\mathrm{A}-\mathrm{Bp} & \mathrm{A}, \mathrm{B}>0 . \\
\mathrm{AC}(\mathrm{q})=\mathrm{Cq}^{2}-\mathrm{Dq}+\mathrm{E} & \mathrm{C}, \mathrm{D}, \mathrm{E}>0 .
\end{array}
$$

Naturally, the parameters have to be chosen such that $A C$ and $D(p)$ satisfy the conditions of the model. As said in section 3, the Ramsey optimal prices are not unique. The Ramsey optimal quantity is easy to calculate. Assume that for all $p: p<A C\left(D(p)-q^{*}\right)$. Let $B=1 ; C=0.25 ; D=6 ; E=40$. The Ramsey quantity is $q=\left[22+2(3 \mathrm{~A}+1)^{1 / 2}\right] / 3$. All feasible prices that yield non-negative profits are Ramsey optimal. The equilibrium of Proposition 2 yields $\mathrm{p}_{1}^{\mathrm{H}}=7.52$ with $\pi_{1}=0.97$. Some welfare comparisons: $\mathrm{W}_{1}=120, \mathrm{~W}_{2}=121.085, \mathrm{~W}_{3}=117.9277$ and Ramsey welfare is 121.1. Shifting with $A$ means shifting with demand and residual demand. The feasible values for a are $16<\mathrm{A}<27$. The results are:

For $16<A<27: W_{2}>W_{i}$ for $i=1,3$.

For $A<21.5: \quad W_{1}>W_{3}$.

For $A>21.5: \quad W_{1}<W_{3}$.

At $A=21.5$ the quantity total $\widetilde{q}+q_{1}^{H}=q^{*}$, so that $W_{1}=W_{3}$. For $A>21.5$ total quantity at Proposition 3 is closer to the Ramsey optimal quantity, so that $\mathrm{W}_{3}>\mathrm{W} 1$. If more than two prices are allowed the 
comparison will be less favourable for differential pricing. For the special case $A=16$ (so that $\left.\mathrm{D}\left(\mathrm{p}^{*}\right) \mathrm{q}^{*}\right)$ Propositions 1 and 2 coincide with the Ramsey optimal outcome. Keeping the parameter A constant and changing another parameter leads to the same results. In general, if $\widetilde{q}$ is small, total quantity is smaller than $q^{*}$, so that $W_{1}>W_{3}$. So the parameters that determine $\widetilde{q}$, determine also which of the two regimes is preferred. Now $\widetilde{q}=A-E B+(D B-1)^{2} / 4 C B$. So for $W_{3}>W_{1}$ one wants e.g. a relatively high residual demand. For the case of $\mathrm{C}=\mathrm{F}+\mathrm{Aq}^{2}$ it implies one wants relatively low fixed costs. For the case where there is positive residual demand for a second firm or: there is a $\mathrm{p}$ such that $p>A C\left(D(p)-q^{*}\right)$, the same results were obtained. Finally, if $A=18, B=1 / 3, C=1 / 6, D=5$ and $E=39.5$, firm 1 has to set $p_{1}^{L} \approx-8.384$ to deter entry if dumping is allowed for all firms.

\section{Concluding Remarks}

Differential pricing can lead to a higher welfare than uniform pricing. The welfare improvement is weakened if the firms are allowed to set more than two prices. Also, if the firms are allowed to price below average costs, welfare decreases. In general, second-best outcomes are not realizable in equilibrium. Whether differential pricing should be allowed or not, depends on how effective the natural monopoly can be regulated. The regulator should try to prohibit both dumping and the setting of more than two prices.

There are two potentially interesting extensions of the model. First, one should consider a dynamic framework. Price discrimination through consumer rationing was studied by Van Cayseele (1991) in an intertemporal framework. However, he does not address the problem of entry deterrence, so that this seems to be a unexplored territory. A second extension is to consider a natural oligopoly, i.e. to drop the assumption of subadditivity of the cost function. Assume that the cost and demand functions are such that $\mathrm{D}\left(\mathrm{p}^{*}\right)$ can be produced most efficiently by two firms rather than one. Let me concentrate on the situation that is analogous to Proposition 2(i). In equilibrium two firms set $\left(\mathrm{p}^{*}, \mathrm{q}^{*}\right)$ and there is residual demand left that cannot be produced by other firms. Contrary to the natural monopoly case, both incumbents can produce the residual demand, so that positive profits will be competed away, so that the competitive outcome emerges, even under differential pricing. 


\section{References}

Baumol W., Panzar J. and Willig R. (1982) Contestable Markets and the Theory of Industry Structure, Harcourt Brace Jovanovich Inc.

Benassy J.P. (1986) "On the Existence of Bertrand-Edgeworth Equilibria with Differentiated Commodities", Contributions to Mathematical Economics, in honor of Gérard Debreu, W. Hildebrand and A. Mas-Colell (eds.), North-Holland.

Braeutigam R.R. (1989) "Optimal Policies for Natural Monopolies", in Handbook of Industrial Organization, Schmalensee and Willig (ed.), North-Holland.

Canoy M. (1993) "Bertrand meets the Fox and the Owl", PhD-thesis, University of Amsterdam.

Cayseele van P. (1991) "Consumer Rationing and the Possibility of Intertemporal Price Discrimination", European Economic Review 35, 1473-1484.

Chander P. and Leruth L. (1989) "The Optimal Product Mix for a Monopolist in the Presence of Congestion Effects", International Journal of Industrial Organization 7, 437-449.

Friedman J. (1988) "On the Strategic Importance of Prices versus Quantities", RAND Journal of Economics 19, 607-622.

Goldman M. Barry, Leland Hayne E. and Sibley David S. (1984) "Optimal Nonuniform Prices", Review of Economic Studies LI, 305-319.

Mandy David M. (1991) "Nonuniform Bertrand Competition", Econometrica 60, 1293-1330.

Panzar J. (1989) "Determinations of Firm and Industry Structure", in Handbook of Industrial Organization, Schmalensee R. and Willig R. (ed.), North-Holland.

Perry M. (1984) "Sustainable Positive Profit Multiple-Price strategies in Contestable Markets", Journal of Economic Theory 32, 246-265.

Scherer F.M. and Ross D. (1990) Industrial Market Structure and Economic Performance, Houghton Mifflin Company, Boston.

Sharkey W. (1982) The Theory of Natural Monopoly, Cambridge University Press, Cambridge.

Thisse J-F. and Vives X. (1988) "On the Strategic Choice of Spatial Price Policy", American Economic Review 78, 122-138.

Tirole J. (1989) The Theory of Industrial Organization, MIT Press.

Varian H. (1989) "Price Discrimination", in Handbook of Industrial Organization, Schmalensee and Willig (ed.), North-Holland. 


\section{Appendix}

\section{Lemma 1}

Let $\left(\mathrm{p}_{1}^{\mathrm{L}}, \mathrm{q}_{1}^{\mathrm{L}}\right)=\left(\mathrm{p}^{*}, \mathrm{q}^{*}\right)$ and let dumping be forbidden for all firms. If firm 1 optimizes under entry-deterring constraints then it never sets $\mathrm{q}_{1}^{\mathrm{H}}<\mathrm{q}^{\mathrm{R}}\left(\mathrm{p}_{1}^{\mathrm{H}}, \mathrm{q}^{*}\right)$ in the optimum.

$\max p_{1}^{\mathrm{H}}, \mathrm{q}_{1}^{\mathrm{H}}, \lambda \quad \Phi=\mathrm{p}^{*} \mathrm{q}^{*}+\mathrm{p}_{1}^{\mathrm{H}} \mathrm{q}_{1}^{\mathrm{H}}-\mathrm{C}\left(\mathrm{q}^{*}+\mathrm{q}_{1}^{\mathrm{H}}\right)+\lambda\left(\mathrm{D}\left(\mathrm{p}_{1}^{\mathrm{H}}\right)-\mathrm{q}^{*}-\mathrm{q}_{1}^{\mathrm{H}}\right)$

FOC: (i) $\quad \Phi_{\mathrm{p}_{1}^{\mathrm{H}}} \mathrm{q}_{1}^{\mathrm{H}}+\lambda \mathrm{D}^{\prime}\left(\mathrm{p}_{1}^{\mathrm{H}}\right) \leq 0$ and $\Phi_{\mathrm{p}_{1}^{\mathrm{H}}}^{\mathrm{H}}=0$ or $\mathrm{p}_{1}^{\mathrm{H}}=0$.

(ii) $\Phi_{\mathrm{q}_{1}^{\mathrm{H}}}: \mathrm{p}_{1}^{\mathrm{H}}-\mathrm{C}^{\prime}\left(\mathrm{q}_{1}^{\mathrm{H}}+\mathrm{q}^{*}\right)-\lambda \leq 0$ and $\Phi_{\mathrm{q}_{1}^{\mathrm{H}}}=0$ or $\mathrm{q}_{1}^{\mathrm{H}}=0$.

(iii) $\Phi_{\lambda}: q_{1}^{H}+q^{*}-D\left(p_{1}^{H}\right) \leq 0$ and $\Phi_{\lambda}=0$ or $\lambda=0$.

It has to be shown that $\lambda=0$ is not feasible in the optimum. Since $\mathrm{p}_{1}^{\mathrm{H}}>\mathrm{p}^{*}>0, \lambda=0$ implies through (i) that $\mathrm{q}_{1}^{\mathrm{H}}=0$. By (ii), $\mathrm{q}_{1}^{\mathrm{H}}=0$ implies $\mathrm{p}_{1}^{\mathrm{H}}-\mathrm{AC}\left(\mathrm{q}^{*}\right) \leq 0$, contradicting $\mathrm{p}_{1}^{\mathrm{H}}>\mathrm{p}^{*}$.

\section{Lemma 2}

Let $\mathrm{p}_{1}^{\mathrm{L}}=\mathrm{p}^{*}$ and only dumping by the incumbent is allowed. If firm 1 optimizes under entry-deterring constraints and $\mathrm{q}_{1}^{\mathrm{L}}=\widetilde{\mathrm{q}}$ then it never sets $\mathrm{q}_{1}^{\mathrm{H}}<\mathrm{q}^{\mathrm{R}}\left(\mathrm{p}_{1}^{\mathrm{H}}, \widetilde{\mathrm{q}}\right)$ in the optimum.

$$
\max p_{1}^{\mathrm{H}}, \mathrm{q}_{1}^{\mathrm{H}}, \lambda, \mu \quad \Phi=\mathrm{p}^{*} \widetilde{\mathrm{q}}+\mathrm{p}_{1}^{\mathrm{H}} \mathrm{q}_{1}^{\mathrm{H}}-\mathrm{C}\left(\widetilde{\mathrm{q}}+\mathrm{q}_{1}^{\mathrm{H}}\right)+\lambda\left(\mathrm{D}(\mathrm{p})-\widetilde{\mathrm{q}}-\mathrm{q}_{1}^{\mathrm{H}}\right)+\mu\left(\mathrm{AC}\left(\mathrm{D}\left(\mathrm{p}_{1}^{\mathrm{H}}\right)-\widetilde{\mathrm{q}}\right)-\mathrm{p}_{1}^{\mathrm{H}}\right)
$$

FOC: (i) $\quad \Phi_{\mathrm{p}_{1}^{\mathrm{H}}:} \mathrm{q}_{1}^{\mathrm{H}}+\lambda \mathrm{D}^{\prime}\left(\mathrm{p}_{1}^{\mathrm{H}}\right)+\mu\left[\mathrm{AC}^{\prime}\left(\mathrm{D}\left(\mathrm{p}_{1}^{\mathrm{H}}\right)-\widetilde{\mathrm{q}}\right) \mathrm{D}^{\prime}\left(\mathrm{p}_{1}^{\mathrm{H}}\right)-1\right]=0$

(ii) $\Phi_{\mathrm{q}_{1}^{\mathrm{H}}}: \mathrm{p}_{1}^{\mathrm{H}}-\mathrm{C}^{\prime}\left(\widetilde{\mathrm{q}}+\mathrm{q}_{1}^{\mathrm{H}}\right)-\lambda=0$

(iii) $\Phi_{\lambda}: \quad \mathrm{D}\left(\mathrm{p}_{1}^{\mathrm{H}}\right)-\widetilde{\mathrm{q}}-\mathrm{q}_{1}^{\mathrm{H}} \geq 0$ and $\Phi_{\lambda}=0$ or $\lambda=0$

(iv) $\Phi_{\mu}: \quad \operatorname{AC}\left(\mathrm{D}\left(\mathrm{p}_{1}^{\mathrm{H}}\right)-\widetilde{\mathrm{q}}\right)-\mathrm{p}_{1}^{\mathrm{H}} \geq 0$ and $\Phi_{\mu}=0$ or $\mu=0$

Formally, constraint (i) must hold for all $\mathrm{p} \leq \mathrm{p}_{1}^{\mathrm{H}}$, but from Definition 3 it follows that $\mu=0$ for all $\mathrm{p}$ except $\widetilde{\mathrm{p}}$, but, by Definition 3, at $\widetilde{\mathrm{p}} \mathrm{AC}^{\prime}\left(\mathrm{D}\left(\mathrm{p}_{1}^{\mathrm{H}}\right)-\widetilde{\mathrm{q}}\right) \mathrm{D}^{\prime}\left(\mathrm{p}_{1}^{\mathrm{H}}\right)-1=0$. Suppose now that $\lambda=0$. From FOC(i) it follows that $\mathrm{q}_{1}^{\mathrm{H}}=0$, which is unfeasible. If $\lambda \neq 0$, it follows that $\mathrm{q}_{1}^{\mathrm{H}}<\mathrm{q}^{\mathrm{R}}\left(\mathrm{p}_{1}^{\mathrm{H}}, \mathrm{q}^{*}\right)$.

Proof of Proposition 1 (see also Sharkey 1982)

(i) No entry can take place given that firm 1 sets $\left(\mathrm{p}^{*}, \mathrm{q}^{*}\right)$, and only one potential firm is needed, with price $\mathrm{p}^{*}$, to make sure firm 1 cannot profitably raise price.

(ii) Since there is residual demand, there are two active firms now and two potential entrants: one with price $\mathrm{p}^{*}$, to ensure firm 1 does not profitably raise its price, and one with price $\mathrm{p}^{\mathrm{R}}\left(\mathrm{q}^{*}\right)$, to ensure firm 2 does not profitably raise its price.

\section{Proof of Proposition 2}

(i) Existence: By (6), $\hat{\mathrm{p}}\left(\mathrm{q}^{*}\right)$ is optimal given $\mathrm{p}_{1}^{\mathrm{L}}=\mathrm{p}^{*}$ and $\mathrm{q}_{1}^{\mathrm{L}}=\mathrm{q}^{*}$. If $\mathrm{p}_{1}^{\mathrm{L}}>\mathrm{p}^{*}$ entry occurs, whereas $\mathrm{p}_{1}^{\mathrm{L}}<\mathrm{p}^{*}$ violates the no-dumping condition. Suppose firm 2 sets a price $p_{2}^{\mathrm{L}}>\mathrm{p}^{*}$. Then there is an $\epsilon>0$ such that firm 1 can increase profit by setting $p_{1}^{L}=p_{2}^{L}-\epsilon>p^{*}$. Given $\left(p_{1}^{L}, p_{1}^{H}, p_{2}^{L}\right)=\left(p^{*}, \widehat{p}^{*}\left(q^{*}\right), p^{*}\right)$, firm 1's optimal quantity must include $\mathrm{q}_{1}^{\mathrm{L}}=\mathrm{q}^{*}$ because of the no-dumping condition, whereas $\mathrm{q}^{\mathrm{R}}\left(\hat{\mathrm{p}}\left(\mathrm{q}^{*}\right), \mathrm{q}^{*}\right)$ is optimal by 
Lemma 1. Finally in a subgame perfect equilibrium $\mathrm{p}_{2}^{\mathrm{H}}=\hat{\mathrm{p}}\left(\mathrm{q}^{*}\right)$, which is the only credible threat if firm 1 would set $\mathrm{p}_{1}^{\mathrm{L}}>\mathrm{p}^{*}$.

Uniqueness: By construction, firm 1 is the only active firm here. The no-dumping condition ensures that entry is only deterred at $\left(\mathrm{p}^{*}, \mathrm{q}^{*}\right)$. Uniqueness follows from the fact that (6) has a unique solution, which is the case if the profit function is quasi-concave:

$$
\begin{aligned}
& \pi^{\prime}=\mathrm{D}(\mathrm{p})-\mathrm{q}^{*}+\mathrm{D}^{\prime}(\mathrm{p})\left[\mathrm{p}-\mathrm{C}^{\prime}(\mathrm{D}(\mathrm{p}))\right]=0 \\
& \pi^{\prime \prime}=2 \mathrm{D}^{\prime}(\mathrm{p})+\mathrm{D}^{\prime \prime}(\mathrm{p})\left[\mathrm{p}-\mathrm{C}^{\prime}(\mathrm{D}(\mathrm{p}))\right]-\mathrm{C}^{\prime \prime}(\mathrm{D}(\mathrm{p}))\left(\mathrm{D}^{\prime}(\mathrm{p})\right)^{2}
\end{aligned}
$$

By Assumption 4 , revenue is concave, so that $\mathrm{pD}^{\prime \prime}<-2 \mathrm{D}^{\prime}$. Substitution and rewriting yields:

$$
\pi^{\prime \prime}=2 \mathrm{D}^{\prime}(\mathrm{p}) \mathrm{C}^{\prime}(\mathrm{D}(\mathrm{p}))-\mathrm{C}^{\prime \prime}(\mathrm{D}(\mathrm{p}))\left(\mathrm{D}^{\prime}(\mathrm{p})\right)^{2}
$$

By Assumption 3, $\mathrm{C}^{\prime \prime}(\mathrm{D}(\mathrm{p}))>0$, implying $\pi^{\prime \prime}<0$, which proves quasi-concavity of the profit function.

(ii) Existence: By Proposition 1, Observation 1 and (7), entry is deterred at $\left(\mathrm{p}_{1}^{\mathrm{L}}, \mathrm{p}_{1}^{\mathrm{H}}, \mathrm{q}_{1}^{\mathrm{L}}, \mathrm{q}_{1}^{\mathrm{H}}\right)=$ $\left(\mathrm{p}^{*}, \hat{\mathrm{p}} ; \mathrm{q}^{*}, \mathrm{q}^{\mathrm{R}}\left(\widehat{\mathrm{p}}, \mathrm{q}^{*}\right)\right)$. The lowest price at which a potential entrant can sell residual demand is $\mathrm{p}^{\mathrm{R}}\left(\mathrm{q}^{*}\right)$. Since $\hat{\mathrm{p}} \leq \mathrm{p}^{\mathrm{R}}\left(\mathrm{q}^{*}\right)$, firm 1 either undercuts $\mathrm{p}^{\mathrm{R}}\left(\mathrm{q}^{*}\right)$ or matches it. In the latter case demand is shared, so that the potential entrant makes a loss if it enters. If $\mathrm{p}_{2}^{\mathrm{L}}>\mathrm{p}^{*}$, firm 1 can increase profit by setting $\mathrm{p}_{1}^{\mathrm{L}}=\mathrm{p}_{2}^{\mathrm{L}}-\epsilon$; if $\mathrm{p}_{2}^{\mathrm{H}}>\mathrm{p}^{\mathrm{R}}$ firm 1 can increase profit by setting $\mathrm{p}_{1}^{\mathrm{H}}=\hat{\mathrm{p}}$; and finally if $\mathrm{p}_{2}^{\mathrm{H}}<\mathrm{p}^{\mathrm{R}}$ firm 1 can also improve by setting $\mathrm{p}_{1}^{\mathrm{H}}=\hat{\mathrm{p}}$, since entry is not threatened at $\mathrm{p}_{2}^{\mathrm{H}}<\mathrm{p}^{\mathrm{R}}$. Given the equilibrium prices $\left(\mathrm{p}_{1}^{\mathrm{L}}, \mathrm{p}_{1}^{\mathrm{H}}, \mathrm{p}_{2}^{\mathrm{L}}, \mathrm{p}_{2}^{\mathrm{H}}\right)=\left(\mathrm{p}^{*}, \hat{\mathrm{p}}, \mathrm{p}^{*}, \mathrm{p}^{\mathrm{R}}\left(\mathrm{q}^{*}\right)\right)$, by the no-dumping constraint and Lemma 1 , firm 1 sets quantities $\left(\mathrm{q}_{1}^{\mathrm{L}}, \mathrm{q}_{1}^{\mathrm{H}}\right)=\left(\mathrm{q}^{*}, \mathrm{q}^{\mathrm{R}}\left(\hat{\mathrm{p}}, \mathrm{q}^{*}\right)\right)$.

Uniqueness: For uniqueness I have to show again that is a unique maximum. It is easy to see that the upper bound which is imposed on $\mathrm{p}_{1}^{\mathrm{H}}$ in (7) does not interfere with the uniqueness proof of Proposition 2(i).

\section{Proof of Proposition 3}

(i) Existence: In a solution of (9) it is not profitable to set $\mathrm{q}_{1}^{\mathrm{L}}>\widetilde{\mathrm{q}}$ because at $\mathrm{q}_{1}^{\mathrm{L}}=\widetilde{\mathrm{q}}$ entry is deterred for all prices already. Given $\mathrm{q}_{1}^{\mathrm{L}}=\widetilde{\mathrm{q}}$, by Lemma 2 firm 1 sets $\mathrm{q}_{1}^{\mathrm{H}}=\mathrm{q}^{\mathrm{R}}\left(\mathrm{p}_{1}^{\mathrm{H}}, \widetilde{\mathrm{q}}\right)$ and by $(6)$ it sets $\mathrm{p}_{1}^{\mathrm{H}}=\hat{\mathrm{p}}(\widetilde{\mathrm{q}})$. By Observation 1 , solving the program under entry-deterring constraints must be combined with entry threats to become an equilibrium. So let firm 2 set $\left(\mathrm{p}_{2}^{\mathrm{L}}, \mathrm{p}_{2}^{\mathrm{H}}\right)=\left(\mathrm{p}^{*}, \hat{\mathrm{p}} \mathrm{q}(\mathfrak{\mathrm { q }})\right)$ then by the same arguments as in Proposition 2 existence of an equilibrium is proved.

Uniqueness: I have to prove that (6) has a unique solution, which is the case if the profit function is quasi-concave:

$$
\begin{aligned}
& \pi^{\prime}=\mathrm{D}\left(\mathrm{p}_{1}^{\mathrm{H}}\right)-\widetilde{\mathrm{q}}+\mathrm{D}^{\prime}\left(\mathrm{p}_{1}^{\mathrm{H}}\right)\left[\mathrm{p}_{1}^{\mathrm{H}}-\mathrm{C}^{\prime}\left(\mathrm{D}\left(\mathrm{p}_{1}^{\mathrm{H}}\right)\right)\right]=0 \\
& \pi^{\prime \prime}=2 \mathrm{D}^{\prime}\left(\mathrm{p}_{1}^{\mathrm{H}}\right)+\mathrm{D}^{\prime \prime}\left(\mathrm{p}_{1}^{\mathrm{H}}\right)\left[\mathrm{p}_{1}^{\mathrm{H}}-\mathrm{C}^{\prime}\left(\mathrm{D}\left(\mathrm{p}_{1}^{\mathrm{H}}\right)\right)\right]-\mathrm{C}^{\prime \prime}\left(\mathrm{D}\left(\mathrm{p}_{1}^{\mathrm{H}}\right)\right)\left(\mathrm{D}^{\prime}\left(\mathrm{p}_{1}^{\mathrm{H}}\right)\right)^{2}
\end{aligned}
$$

By Assumption 4 revenue is concave, so that $\mathrm{pD}^{\prime \prime}<-2 \mathrm{D}^{\prime}$. Substituting and rewriting yields:

$$
\pi^{\prime \prime}=2 \mathrm{D}^{\prime}\left(\mathrm{p}_{1}^{\mathrm{H}}\right) \mathrm{C}^{\prime}\left(\mathrm{D}\left(\mathrm{p}_{1}^{\mathrm{H}}\right)\right)-\mathrm{C}^{\prime \prime}\left(\mathrm{D}\left(\mathrm{p}_{1}^{\mathrm{H}}\right)\right)\left(\mathrm{D}^{\prime}\left(\mathrm{p}_{1}^{\mathrm{H}}\right)\right)^{2}
$$

By Assumption 3, $\mathrm{C}^{\prime \prime}>0$ so that $\pi^{\prime \prime}<0$.

(ii) This follows by construction. Let there be a $\left(\mathrm{q}_{1}^{\mathrm{L}}, \mathrm{q}_{1}^{\mathrm{H}}\right)$ with $\mathrm{q}_{1}^{\mathrm{L}}<\widetilde{\mathrm{q}}$ such that $\pi_{1}\left(\mathrm{p}^{*}, \mathrm{p}^{\mathrm{R}}\left(\mathrm{q}_{1}^{\mathrm{L}}\right) ; \mathrm{q}_{1}^{\mathrm{L}}, \mathrm{q}_{1}^{\mathrm{H}}\right)>$ $\pi_{1}\left(\mathrm{p}^{*}, \hat{\mathrm{p}}(\widetilde{\mathrm{q}}) ; \widetilde{\mathrm{q}}, \mathrm{q}^{\mathrm{R}}(\hat{\mathrm{p}}(\widetilde{\mathrm{q}}), \widetilde{\mathrm{q}})\right)$. By continuity of the profit function and compactness of the constraint set, there exists a pair $\left(\mathrm{q}_{1}^{\mathrm{L}}, \mathrm{q}_{1}^{\mathrm{H}}\right)$ yielding the highest profit. 


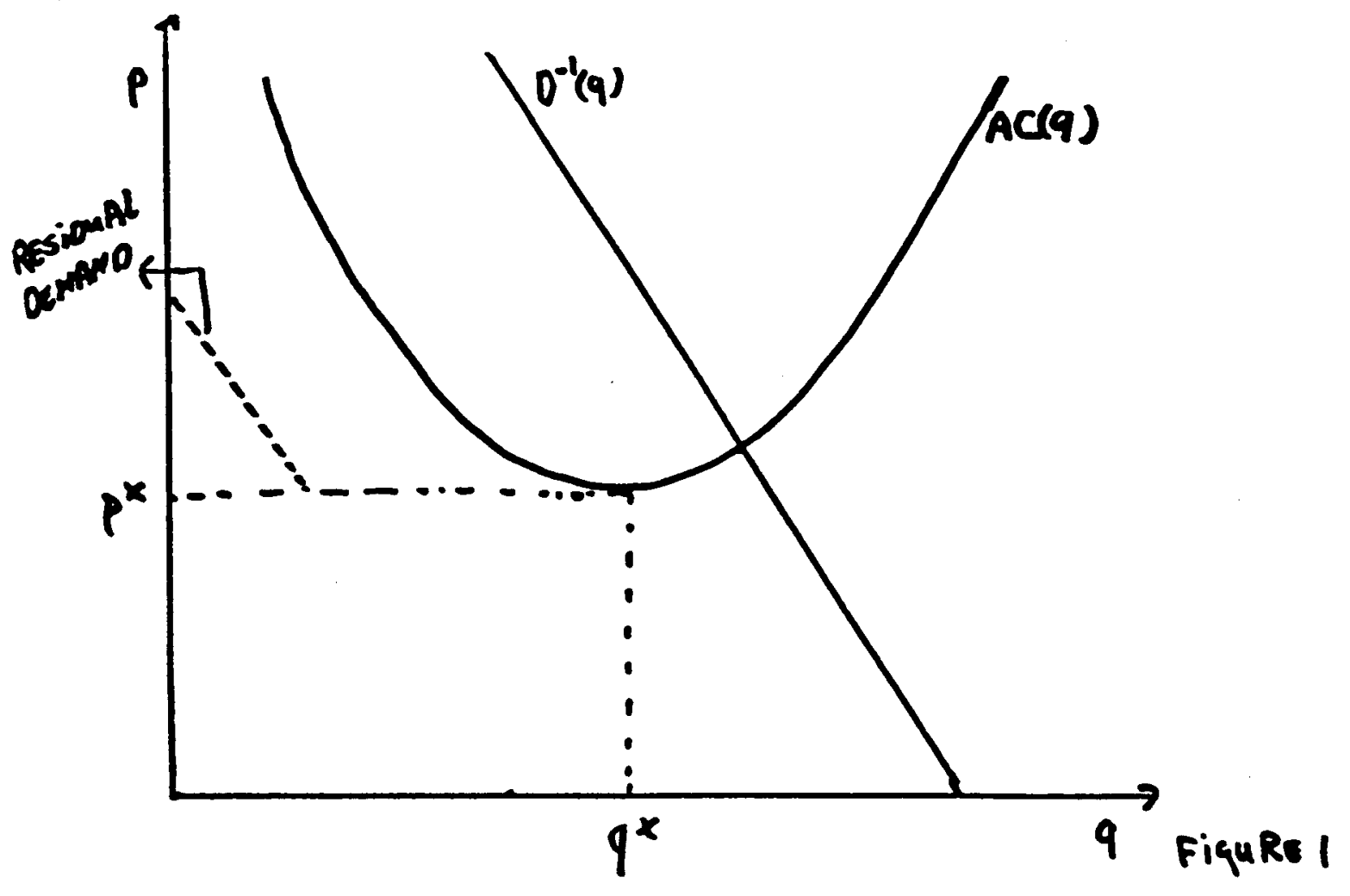

(PROVI SIONAL)

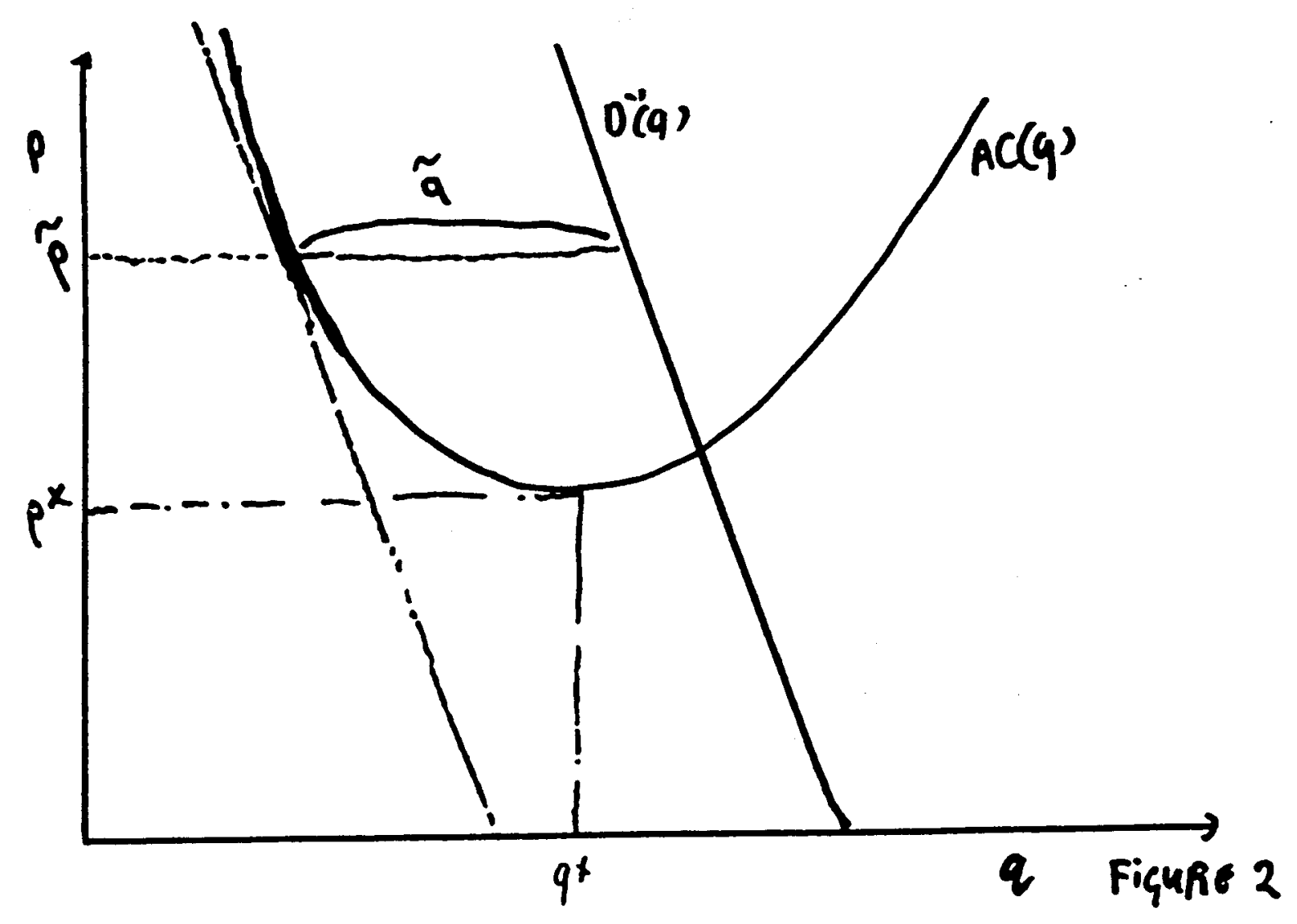

